ISSN : $2302-1590$

E-ISSN: $2460-190 \mathrm{X}$

ECONOMICA

Journal of Economic and Economic Education Vol.1 No.2 (231-237)

\title{
PENGARUH KEPEMIMPINAN DAN MOTIVASI KERJA TERHADAP KINERJA KARYAWAN PADA PERUSAHAAN DAERAH AIR MINUM (PDAM) KOTA PADANG
}

\author{
Meri Oposma $^{1}$ Rizky Natassia ${ }^{2}$ Yosi Eka Putri ${ }^{3}$ \\ Mahasiswa Program Studi Pendidikan Ekonomi ${ }^{1}$ Dosen Program Studi Akutansi Universitas \\ Negeri Padang ${ }^{2}$ Dosen Program Studi Pendidikan Ekonomi STKIP- PGRI Sumbar ${ }^{3}$ \\ Jl. Gunung Pangilun No.1, Padang Sumatera Barat. \\ Email: Merioposma@gmail.com
}

submited: 2013.01.20 reviewed: 2013.02.28 accepted: 2013.04 .29

http://dx.doi.org/10.22202/economica.2013.v1.i2.124

\begin{abstract}
Abstrak
Sumber daya manusia merupakan faktor yang menentukan keberhasilan suatu organisasi dalam mencapai suatu tujuan. Upaya harus dilakukan untuk meningkatkan kinerja karyawan, antara lain, dengan kepemimpinan yang baik dan motivasi di tempat kerja tinggi. tujuan yang dapat dicapai dari penelitian ini adalah untuk mengetahui, pengaruh atau kepemimpinan dan motivasi terhadap kinerja karyawan di Perusahaan Daerah Air Minum (PDAM) Kota Padang. Objek studi penelitian ini adalah karyawan Perusahaan Daerah Air Minum (PDAM) Kota Padang dengan jumlah penduduk 113 orang berarti karyawan. Penelitian ini menggunakan sampel 85 orang yang dipilih dengan teknik cluster random sampling. Teknik analisis yang digunakan adalah analisis jalur. Diperoleh dalam jumlah parsial pengaruh kepemimpinan terhadap motivasi kerja karyawan sejumlah 0.231 dengan makna signifikan hipotesis 0034 berpengaruh positif dan signifikan antara variabel kepemimpinan motivasi kerja, diperoleh di sejumlah pengaruh parsial kepemimpinan terhadap kinerja karyawan adalah sebesar 0,291 dengan rata-rata 0,007 signifikan positif dan signifikan berpengaruh hipotesis antara variabel kepemimpinan terhadap kinerja karyawan, diperoleh di sejumlah pengaruh parsial motivasi kerja terhadap kinerja karyawan adalah sebesar 0,212 dengan rata-rata 0,045 signifikan positif dan signifikan berpengaruh hipotesis antara variabel motivasi kerja terhadap kinerja karyawan dan diperoleh dalam sejumlah
\end{abstract}

\section{Abstract}

Human resources is a factor that determines the success of an organization in achieving a goal. Efforts should be made to improve the performance of employees, among others, with good leadership and motivation in the workplace is high. Attainable goal of this study was to determine, influence or leadership and motivation on employee performance in Perusahaan Daerah Air Minum (PDAM) Kota Padang. Object of study the research is employee to Perusahaan Daerah Air Minum (PDAM) Kota Padang with population a mean 113 people employee. This study used a sample of 85 people selected by random cluster sampling technique. Analysis technique used is path analysis. Obtained in a partial amount of leadership influence on job motivation employee amount 0,231 with significant meaning hypotheses 0,034 positive and significant effect between leadership variables to job motivation, obtained in a number of partial influence of leadership on employee performance is equal to 0.291 with a mean of 0.007 significant positive and significant effect hypothesis between the variables of leadership on employee performance, obtained in a number of partial influence of work motivation on the performance of employees is equal to 0.212 with a mean of 0.045 significant positive

Keywords: Leadership, Motivation, employee Performance and Path Analysis 


\section{PENDAHULUAN}

Unsur manusia tidak terlepas dari keikutsertaannya dalam menunjang majunya suatu perusahaan, walaupun banyak unsur teknologi yang menggantikannya akan tetapi peranan manusia tetap merupakan unsur yang terpenting dalam menunjang kerja perusahaan dan untuk mencapai tujuan perusahaan. Keberadaan sumber daya manusia di dalam suatu perusahaan memegang peranan yang sangat penting.

Sumber daya manusia yang berkualitas dapat dinilai dari hasil kerjanya, karena dalam kerangka profesionalisme kinerja yang baik seorang karyawan harus mampu memperlihatkan perilaku kerja yang mengarah pada tercapainya maksud dan tujuan perusahaan. Agar dapat mengarah pada hasil kinerja yang baik maka sumber daya manusia harus dikelola dengan baik, karena manusia bisa menjadi pusat persoalan bagi perusahaan ketika potensi mereka tidak dikembangkan secara optimal.

Keberhasilan merupakan aktualisasi potensi diri sekaligus peluang untuk memenuhi kebutuhan hidup bagi seorang pegawai. Sedangkan bagi perusahaan, keberhasilan merupakan sarana menuju pertumbuhan dan perkembangan perusahaan. Seiring dengan perkembangannya, perusahaan sering kali mengabaikan tentang pengelolaan sumber daya manusia yang dimilikinya.

Kinerja merupakan sarana untuk memperbaiki mereka yang tidak melakukan tugasnya dengan baik di dalam organisasi. Banyak organisasi yang berusaha mencapai sasaran suatu kedudukan yang terbaik dan terpercaya dalam bidangnya. Untuk itu sangat tergantung dari para pelaksananya, yaitu para karyawan agar mereka mencapai sasaran yang telah ditetapkan oleh organisasi. Kinerja digunakan untuk penilaian atas keberhasilan atau kegagalan pelaksanaan kegiatan, program, kebijakan sesuai dengan sasaran dan tujuan yang telah ditetapkan dalam rangka mewujudkan misi dan visi organisasi. Mangkunegara (2001: 67), mendefinisikan kinerja adalah sebagai hasil kerja secara kualitas dan kuantitas yang dicapai oleh seseorang pegawai dalam kemampuan melaksanakan tugasnya sesuai dengan tanggungjawab yang diberikan kepadanya. Penilaian kinerja digunakan sesuai dasar untuk mengalokasikan penghargaan, keputusan tentang siapa yang mendapatkan peningkatan pembayaran yang pantas dan penghargaan lainnya ditentukan dengan penilaian kinerja.

Untuk mewujudkan kinerja yang optimal tentunya dipengaruhi oleh beberapa faktor, antara lain peran kepemimpinan. Kepemimpinan berarti melibatkan orang atau pihak lain yaitu para karyawan atau bawahan (follower). Pemimpin yang baik adalah meruapakan hal yang sangat penting dalam bisnis, pemerintahan, dan pada orgaisasi serta kelompok yang menciptakan pola hidup, bekerja, dan bermain karena pemimpin mempunyai fungsi sebagai penggerak atau dinamisator dan koordinator dari sumber daya, sumber daya alam, semua dana, dan sarana yang disiapkan. Sebab pemimpin sebagai faktor yang mengarahkan organisasi dan juga memberi contoh perilaku terhadap para pegawai peran pemimpin sangat menentukan kemajuan dan kemunduran organisasi (Mas'ud 2004: 37).

Faktor yang sangat dan hampir selalu dikaji dalam penelitian kinerja adalah faktor motivasi, dimana faktor motivasi merupakan pandangan atau teori tentang motif yang didorong karena kebutuhankebutuhan berprestasi, harapan yang menyatakan bahwa setiap orang memiliki tantangan tertentu yang mengakibatkan seseorang menjadi suka dan senang melakukannya, insentif dipengaruhi oleh rangsangan eksternal. Motivasi kerja terbentuk dari sikap individu dalam menghadapi situasi kerja dalam organisasi. Motivasi kerja merupakan kondisi atau energi yang menggerakkan diri individu yang terarah atau tertuju untuk mencapai 
tujuan organisasi, sikap mental individu yang setuju dan positif terhadap situasi kerja itulah yang memperkuat untuk mencapai kinerja dengan hasil yang maksimal.

\section{METODOLOGI PENELITIAN}

Penelitian ini termasuk penelitian kuantitatif dengan menggunakan metode penelitian deskriptif dan asosiatif (Iskandar, 2009:61). Penelitian dengan metode deskriptif adalah penelitian yang dilakukan untuk mengetahui nilai variabel mandiri baik satu variabel atau lebih tanpa membuat perbandingan atau menghubungkan dengan variabel yang lain. Sedangkan asosiatif merupakan penelitian yang bertujuan untuk mengetahui hubungan antar variabel penyebab dengan variabel terikat.

Populasi adalah keseluruhan objek penelitian (Arikunto, 2006:130). Populasi dalam penelitian ini adalah semua karyawan di Perusahaan Daerah Air Minum (PDAM) Kota Padang yang berjumlah 113 karyawan.

Sampel penelitian ini adalah sebagian dari populasi yang terpilih dan mewakili populasi tersebut yang dijadikan responden penelitian (Yusuf, 2007:186). Berkaitan dengan penentuan sampel, tabel yang digunakan adalah tabel Krecjie (Sugiyono, 2012:86), dengan perhitungan sampel didasarkan atas kesalahan 5\%. Jadi penentuan sampel dengan cara menarik ketentuan populasi dari tingkat kesalahan $5 \%$ atau sampel berjumlah 84 . Selanjutnya populasi tiap sub sampel dibagi dengan total populasi dikalikan dengan tingkat kesalahan yaitu 84 dari 5\%. Teknik yang digunakan dalam pengambilan sampel yaitu dengan teknik cluster random samling yaitu pengambilan sampel berdasarkan kelompok yang diambil secara acak, adapun pengambilan sampel dilakukan dengan cara undian (Sugiyono, 2007:64).

\section{Analisis Diskriptif.}

Analisis diskriptif dimaksudkan untuk mendapatkan gambaran penyebaran hasil penelitian masing-masing variabel secara kategorial. Diskriptif yang dimaksudkan mengenai kondisi nyata kepemimpinan, motivasi kerja dan kinerja karyawan pada Perusahaan Daerah Air Minum (PDAM) Kota Padang.

\section{Analisis Data}

Analisis data yang digunakan adalah Analisis Jalur (path analysis). Analisis jalur (path analysis) adalah uji yang dipakai untuk menganalisis pola hubungan kausal antar variabel dengan tujuan untuk mengetahui pengaruh langsung dan tidak langsung, secara serempak atau mandiri beberapa variabel penyebab terhadap sebuah variabel akibat. Dalam pengolahan data yang didapatkan proses perhitungan regresi dengan menggunakan SPSS versi 15.

\section{PEMBAHASAN \\ Deskripsi Data}

Kinerja pada Perusahaan Daerah Air Minum (PDAM) Kota Padang menurut hasil analisis deskriptif diperoleh mean atau rata-rata 4,28 dengan tingkat capaian responden sebesar 80,72 yang terletak pada rentang skala $80-100 \%$ dalam kategori tinggi. Dengan demikian dapat dikatakan bahwa Kinerja pada Perusahaan Daerah Air Minum (PDAM) Kota Padang adalah tinggi.

Kepemimpinan pada Perusahaan Daerah Air Minum (PDAM) Kota Padang menurut hasil analisis deskriptif diperoleh mean atau rata-rata 4,12 dengan tingkat capaian responden sebesar 81,72 yang terletak pada skala $80-100 \%$ dalam kategori tinggi. Dengan demikian dapat dikatakan bahwa Kepemimpinan pada Perusahaan Daerah Air Minum (PDAM) Kota Padang adalah tinggi.

Motivasi kerja pada Perusahaan Daerah Air Minum (PDAM) Kota Padang menurut hasil analisis deskriptif diperoleh mean atau rata-rata 4,14 dengan tingkat capaian responden sebesar 82,85 yang terletak pada skala $80-100 \%$ dalam kategori tinggi. Dengan demikian dapat dikatakan bahwa Motivasi kerja pada 
Perusahaan Daerah Air Minum (PDAM)

Kota Padang adalah tinggi.

Analisis Jalur (path analysis)
Hasil analisis jalur (path analysis) dengan menggunakan progran SPSS, dapat diketahui persamaan yang digambarkan sebagai

berikut:

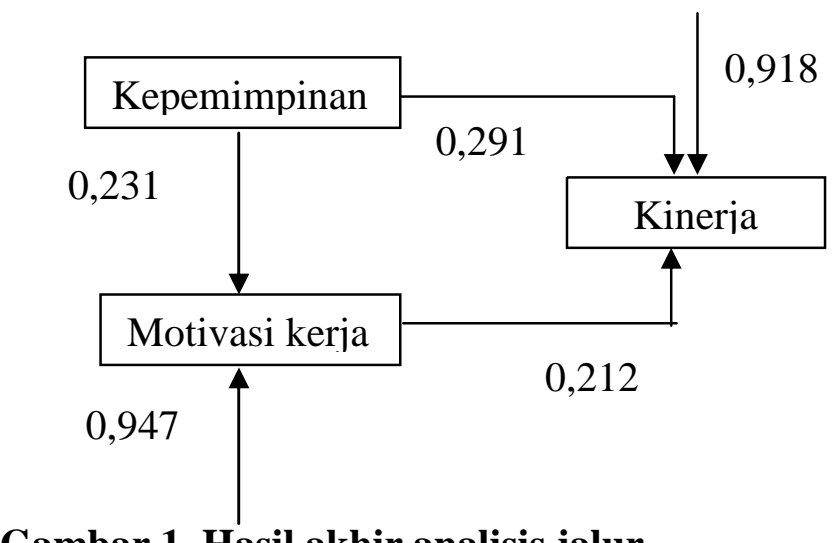

Gambar 1. Hasil akhir analisis jalur

Hasil analisis dapat diketahui bahwa variabel bebas yang paling berpengaruh adalah variabel kepemimpinan dengan koefisien 0,291. Kemudian diikuti oleh variabel motivasi kerja dengan koefisien 0,212 . Dari persamaan tersebut dapat terlihat bahwa semua variabel bebas yaitu kepemimpinan $\left(\mathrm{X}_{1}\right)$ dan motivasi kerja $\left(\mathrm{X}_{2}\right)$ berpengaruh positif terhadap kinerja karyawan (Y). Kondisi ini mengandung arti bahwa dengan meningkatnya kepemimpinan $\left(\mathrm{X}_{1}\right)$ dan motivasi kerja $\left(\mathrm{X}_{2}\right)$ mengakibatkan peningkatkan kinerja pegawai.

Pengaruh Kepemimpinan Terhadap Motivasi Kerja Perusahaan Daerah Air Minum (PDAM) Kota Padang

Berdasarkan hasil olahan data, selanjutnya sesuai dengan hipotesis pertama yang berbunyi: Terdapat Pengaruh yang Positif dan Signifikan antara Kepemimpinan terhadap Motivasi Kerja Karyawan. Artinya perbaikan motivasi kerja karyawan dapat meningkat dengan cara melakukan perbaikan pada kepemimpinan pada Perusahaan Daerah Air Minum (PDAM) Kota Padang. Adapun hal yang dapat dilakukan dalam meningkatkan motivasi kerja oleh seorang pimpinan yaitu dengan cara memberikan dorongan secara langsung kepada karyawan dengan bantuan moril maupun non-moril serta dengan menambah sarana dan prasana kerja karyawan seperti meja kerja, kursi kerja dan komputer serta ruang kerja yang nyaman.

Hasil penelitian deskriptif menunjukan bahwa dari ketiga indikator variabel kepemimpinan di Perusahaan Daerah Air Minum (PDAM) Kota Padang, keseluruhan indikatornya masuk dalam kategori sangat baik. Artinya kepemimpinan pada Perusahaan Daerah Air Minum (PDAM) Kota Padang diukur dengan tiga indikator ini masih kurang cukup dan perlu ditingkatkan lagi.

Berdasarkan teori yang telah dikemukakan di atas dan hasil penelitian maka dapat dijelaskan bahwa Kepemimpinan yang dilakukan oleh Karyawan akan berpengaruh signifikan terhadap motivasi kerja yang dimiliki oleh karyawan tersebut. Dengan demikian karyawan pada Perusahaan Daerah Air Minum (PDAM) Kota Padang ini harus lebih ditingkatkan lagi Kepemimpinannya agar dapat memperoleh motivasi kerja yang lebih baik.

Pengaruh Kepemimpinan Terhadap Kinerja karyawan Perusahaan Daerah Air Minum (PDAM) Kota Padang

Berdasarkan hasil olahan data, selanjutnya sesuai dengan hipotesis kedua yang diajukan berbunyi: Terdapat Pengaruh yang signifikan antara 
Kepemimpinan terhadap Kinerja Karyawan. Kepemimpinan yang dirasakan oleh para karyawan masih belum sesuai dengan keinginan para karyawan tersebut. Kepemimpinan yang diadakan pada Perusahaan Daerah Air Minum (PDAM) Kota Padang cukup optimal ini terlihat masih kurang efektifnya pimpinan dalam menjalankan fungsi-fungsinya sebagai seorang pimpinan. Hal ini tergambar dari hasil analisis deskriptif bahwa dalam indikator bersikap adil seorang pimpinan masih dikategorikan cukup.

Kepemimpinan yang efektif itu secara ringkas menggambarkan pola kerja yang ditunjang oleh kebersamaan, persahabatan, keterbukaan, senang menyelesaikan masalah, tidak membiarkan masalah itu berkembang. Berdasarkan teori yang telah dikemukakan di atas dan hasil penelitian maka dapat dijelaskan bahwa Kepemimpinan yang dilakukan oleh pegawai akan berpengaruh signifikan terhadap kinerja pegawai pada Perusahaan Daerah Air Minum (PDAM) Kota Padang. Dengan demikian pada Perusahaan Daerah Air Minum (PDAM) Kota Padang ini harus lebih ditingkatkan lagi kepemimpinananya agar dapat memperoleh kinerja yang lebih baik.

\section{Pengaruh Motivasi Kerja Terhadap Kinerja karyawan Perusahaan Daerah Air Minum (PDAM) Kota Padang}

Berdasarkan hasil olahan data, selanjutnya sesuai dengan hipotesis ketiga yang diajukan berbunyi: Terdapat Pengaruh yang signifikan antara Motivasi Kerja terhadap Kinerja Karyawan. Ini menunjukan bahwa Kinerja karyawan dapat ditingkatkan dengan cara meningkatkan Motivasi yang dapat meningkatkan Kinerja karyawan yaitu dengan cara memberikan motivasi secara langsung dan secara tidak langsung terhadap karyawan tersebut.

Hasil penelitian menunjukan bahwa terdapat pengaruh yang signifikan antara Motivasi Kerja terhadap Kinerja karyawan. Signifikansi pengaruh variabel
Motivasi kerja terhadap kinerja karyawan ditentukan oleh saling mendukungnya dan saling berhubungannya avariabel yang diteliti satu sama lainnya.

Hasil penelitian deskriptif menunjukan bahwa dari kelima indikator dalam variabel Motivasi kerja pada Perusahaan Daerah Air Minum (PDAM) Kota Padang, semua indikator mempunyai tingkat capaian jawaban responden dengan kategori sangat baik. Artinya karyawan di Prusahaan Daerah Air Minum (PDAM) Kota Padang diukur rata-rata sudah tergolong memiliki motivasi kerja yang tinggi dalam bekerja namun hal ini harus dapat lebih dioptimalkan lagi agar dapat mencapai tujuan yang telah ditetapkan dengan baik.

Hasil penelitian ini sejalan dengan pendapat Thoha (2007 : 200), mengungkapkan motivasi kerja merupakan salah satu faktor yang dapat mempengaruhi Kinerja karyawan yaitu: "faktor motivasi merupakan daya gerak mencakup dorongan, alasan dan kemamuan yang timbul dalam diri seseorang yang menyebabkan ia berbuat sesuatu, misalnya seseorang karyawan menerima gaji, imbalan sesuai dengan kualifikasi pendidikan yang dimilikinya maka kinerjanya akan meningkat". Untuk itu motivasi kerja sebagai variabel intervening dalam penelitian ini sangat perlu diperhatikan dan ditingkatkan lagi. Karena motivasi kerja merupakan variabel kunci dalam meningkatkan kinerja pada karyawan pada Perusahaan Daerah Air Minum (PDAM) Kota Padang.

\section{Pengaruh Kepemimpinan dan Motivasi Kerja Terhadap Kinerja Karyawan Perusahaan Daerah Air Minum (PDAM) Kota Padang}

Berdasarkan hasil olahan data, selanjutnya sesuai dengan hipotesis keempat yang diajukan berbunyi: Terdapat Pengaruh yang signifikan antara Kepemimpinan dan Motivasi Kerja terhadap Kinerja Karyawan, ini menunjukan bahwa Kinerja Karyawan 
dapat ditingkatkan dengan cara meningkatkan Kepemimpinan yang dapat mendorong motivasi kerja karyawan sehingga kinerja dapat ditingkatkan. Ditemukan bahwa kepemimpinan berpengaruh positif dan signifikan terhadap kinerja karyawan. Hal ini juga didukung oleh Suparmi (2010) bahwa pengaruh kepemimpinan seseorang akan berpengaruh positif dan signifikan terhadap tingkat kinerja yang dihasilkan dalam bekerja.

Untuk pengujian hipotesis kedua ditemukan bahwa kepemimpinan dan motivasi kerja berpengaruh positif dan signifikan terhadap kinerja karyawan Perusahaan Daerah Air Minum (PDAM) Pusat Padang. Hal ini juga didukung oleh Thoha (2007 :203) bahwa motivasi seseorang dalam bekerja akan dapat mempengaruhi kinerja seseorang dalam melaksanakan tugasnya. Selanjutnya hal ini juga didukung oleh penelitian terdahulu yang dilakukan oleh Watimena (2007) dimana ia menyatakan bahwa besarnya pengaruh motivasi kerja karyawan terhadap kinerja karyawan berpengaruh positif dan signifikan.

Signifikansinya kepemimpinan dan motivasi kerja dari penelitian ini disebabkan karena Perusahaan Daerah Air Minum (PDAM) Kota Padang selalu memberikan motivasi dan mengupayakan kepusaan bagi karyawan dalam bekerja. Hal ini dapat juga dilihat dari upaya yang dilakukan Perusahaan Air Minum (PDAM) Kota Padang untuk memotvasi karyawannya seperti pemberian kompensasi yang sesuai, selalu menjaga hubungan baik antara pimpinan dan bawahan, memberikan fasilitas dalam bekerja, memperhatikan lingkungan kerja karyawan tersebut.

Pengaruh langsung kepemimpinan terhadap kinerja karyawan lebih besar jika dibandingkan dengan pengaruh tidak langsung kepemimpinan terhadap kinerja karyawan melalui motivasi kerja karyawan. Ini menunjukan bahwa untuk menciptakan kinerja bagi para karyawan sangat diperlukan kepemimpinan yang baik dan efektif. Selanjutnya motivasi kerja memberikan pengaruh yang paling besar dan dominan dalam meningkatkan kinerja para karyawan jika dibandingkan dengan kepemimpinan, namun motivasi kerja seorang karyawan ini juga tidak terlepas dari peran seorang pimpinan dalam menjalankan fungsi-fungsinya dengan efektif dan baik.

Motivasi kerja sebagai variabel intervening dalam penelitian ini jelas terlihat sangat memberikan pengaruh atau dampak terhadap kinerja para karyawan pada Perusahaan daerah air Minum (PDAM) Kota Padang. Hal ini terlihat dari hasil perhitungan pengaruh langsung dan tidak langsung dimana pada saat perhitungan pengaruh langsung motivasi memberikan sumbangan kontribusi yang cukup besar terhadap kinerja karyawan.

Untuk itu motivasi kerja sebagai variabel intervening dalam penelitian ini sangat perlu diperhatikan dan ditingkatkan lagi. Karena motivasi kerja merupakan variabel kunci dalam meningkatkan kinerja karyawan pada Perusahaan Daerah Air Minum (PDAM) Kota Padang. Hasil penelitian menunjukan bahwa terdapat pengaruh yang signifikan antara Kepemimpinan dan Motivasi Kerja terhadap Kinerja Karyawan. Bentuk hubungan tersebut adalah positif dimana semakin baik Kepemimpinan dan Motivasi Kerja maka Kinerja Karyawan juga akan semakin baik.

\section{KESIMPULAN}

1. Terdapat pengaruh positif dan signifikan antara fungsi kepemimpinan terhadap motivasi kerja karyawan pada Perusahaan Daerah Air Minum (PDAM) Kota Padang dengan koefisien jalur 0,231. Artinya peningkatan motivasi kerja karyawan dapat dilakukan dengan melakukan perbaikan terhadap kepemimpinan pada Perusahaan Daerah Air Minum (PDAM) Kota Padang. Hal ini dapat dilakukan dengan cara memberikan 
kelengkapan kerja karyawan serta memberikan kompensasi dan bonus terhadap krayawan yang berprestasi.

2. Terdapat pengaruh yang positif dan signifikan antara fungsi kepemimpinan terhadap kinerja karyawan pada Perusahaan Daerah Air Minum (PDAM) Kota Padang dengan koefisien jalur 0,291. Artinya peningkatan kinerja karyawan dapat dilakukan dengan melakukan perbaikan terhadap kepemimpinan pada Perusahaan Daerah Air Minum (PDAM) Kota Padang. Perbaikan ini dapat dilakukan dengan mengubah cara memimpinnya yaitu dengan bersikap adil terhadap seluruh karyawan.

3. Terdapat pengaruh yang positif dan signifikan antara fungsi motivasi kerja terhadap kinerja karyawan pada Perusahaan Daerah Air Minum (PDAM) Kota Padang dengan koefisien jalur 0,212. Artinya peningkatan kinerja karyawan dapat dilakukan dengan melakukan perbaikan terhadap motivasi kerja karyawan pada Perusahaan Daerah Air Minum (PDAM) Kota Padang. Dapat dilakukan dengan cara menambah sarana dan prasarana untuk kegiatan kerja karyawan yaitu meja kerja, kursi, kenyamanan ruangan dan lain sebagainya.

4. Terdapat pengaruh yang positif dan signifikan antara variabel kepemimpinan dan motivasi kerja terhadap kinerja karyawan pada Perusahaan Daerah Air Minum (PDAM) Kota Padang. Diperoleh nilai $F_{\text {hitung }}$ sebesar 7,692 dengan nilai signifika sebesar 0,001 . Nilai sig < dari $\boldsymbol{\alpha}$ yaitu $(0,001<0,05)$ dengan demikian dapat diartikan bahwa variabel kepemimpinan dan motivasi kerja secara bersama-sama berpengaruh signifikan terhadap kinerja karyawan.

5. Nilai R square sebesar 0,144 menunjukan bahwa besarnya pengaruh kepemimpinan dan motivasi kerja terhadap kinerja karyawan adalah sebesar $14,40 \%$ dan sisanya $85,60 \%$ dipengaruh oleh variabel lain yang tidak termasuk kedalam model penelitian.

\section{DAFTAR PUSTAKA}

10.22202/economica.2013.v1.i2.124

A.Muri Yusuf. 2007. Metodologi Penelitian. Padang : UNP Press

Arikunto, Suharsimi 2006. Prosedur Penelitian Suatu Pendekatan Praktek. Rineka Cipta. Jakarta

Mangkunegara, Anwar Prabu. 2001. Manajemen Sumber Daya Manusia Perusahaan, cetakan ketiga. PT Remaja Rosdakarya Offset. Bandung

Mas'ud, Fuad. 2004. Survai diagnosis Organisasional, konsep dan aplikasi. Semarang: Universitas Dipenegoro

Nitisesmito. 2004. Manajemen Personalia. Ghalia Indonesia. Jakarta

Sopiah. 2008. Perilaku Organisasi. CV ANDI OFFSET. Yogyakarta

Sugiyono. 2012. Metode Penelitian Kuantitatif, Kualitatif dan $R \quad \& \quad D$. Bandung: Alfabeta 